\title{
The conservation of historical architectural heritage in Russia
}

\author{
Ekaterina Balzannikova ${ }^{1, *}$, Vitaliy Samogorov ${ }^{1}$ \\ ${ }^{1}$ Samara State Technical University, Institute of Architecture and Civil Engineering, 194, \\ Molodogvardeyskaya St, 194, 443001, Samara, Russia
}

\begin{abstract}
Much of the historically valuable architectural fabric of the city of Samara is currently in an unsatisfactory condition. Therefore it is advisable to develop and implement effective measures for the conservation and renewal of architectural heritage. This article describes a comprehensive method for the preservation of urban architectural properties of historical and cultural value. The proposed systematic approach enables the scope of renewal works to be justified. Furthermore, its implementation should result in a raised profile and increased tourist visitor numbers for heritage properties and their adjacent areas. The proposed method facilitates both the creation and the regeneration of spaces for recreation and consequently an increase in foot-fall within the adjacent social infrastructure, as part of a general broadening of the cultural-aesthetic life of the city.
\end{abstract}

\section{Introduction}

In the central regions of Russia, large cities founded on the banks of major rivers have a rich history. Such factors as natural resources and transport routes, facilitating industrial production and trade, have played an important role in the development and improvement of cities. In particular, the construction of industrial facilities which were large in their day, became vital for the formation of the historical character of Russian cities [1-5].

The authors' research on historically valuable architectural constructions in Samara has shown that many buildings are collapsing and may well be lost forever [6-11]. As an example, Figure 1 shows the current condition of one of the Samara Maslennikov factory workshops. The building is unoccupied, and the factory isn't functioning. At the same time, there is a wealth of international experience in the renewal and conservation of historically valuable buildings and constructions; for example, in the Polish city of Krakow [12].

\section{Materials and methods}

On the basis of the above-mentioned facts, it may be concluded that the urgent focus of town planning policy should be the development and realization of effective measures for the conservation and renewal of historical architectural heritage, with consideration of the specifics of style and form of each building and its details. Such measures should be

\footnotetext{
*Corresponding author: balzannikova@mail.ru
} 
systematic and based on rigorous research; in particular, the current condition of the building and its existing immediate urban environment are to be taken into consideration.

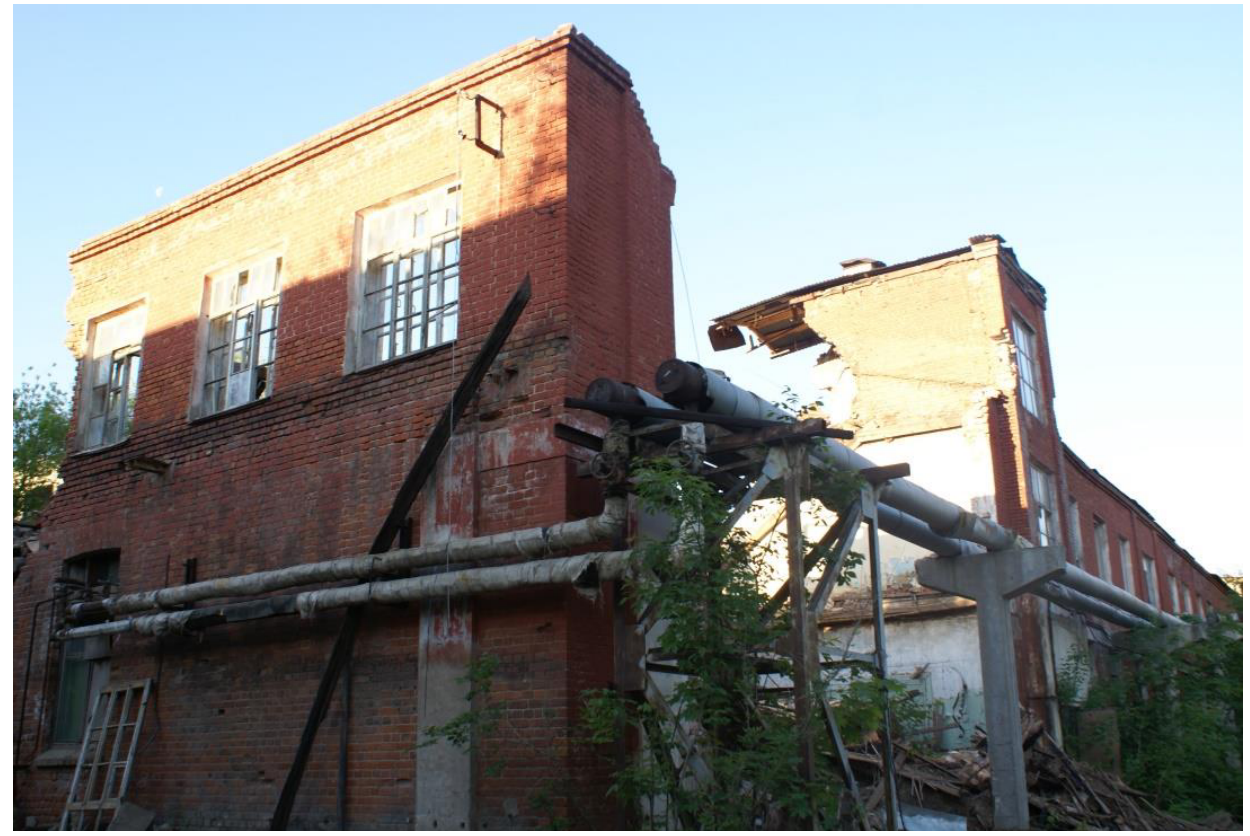

Fig.1. Current condition of one of the factory buildings in Samara.

\section{Results}

The authors suggest that the development of a systematic method for the conservation of historical architectural heritage should consist in the following stages [12]:

1. the research stage, including the following procedures: investigation of the town planning features of the immediate urban environment, assessment of the historical and architectural value of the property, assessment of the dilapidation of the property and its suitability for further exploitation, assessment of the relationship between the property under investigation and the architectural character of the surrounding properties, and the development of a conservation programme;

2. the preparatory stage, involving investigations of the extent of wear and dilapidation of the property, the development of technologies for structural reinforcement, the delivery of building materials and the preparation of the construction site for renovation works;

3 . the construction stage, including the removal of defunct structural elements, assembly and installation of new constructional elements, interior finishing works and renovation of the façades;

4. the completion stage, characterized by: historical and architectural evaluation of the restored property in relation to the aesthetic and architectural character of the adjacent territory. 


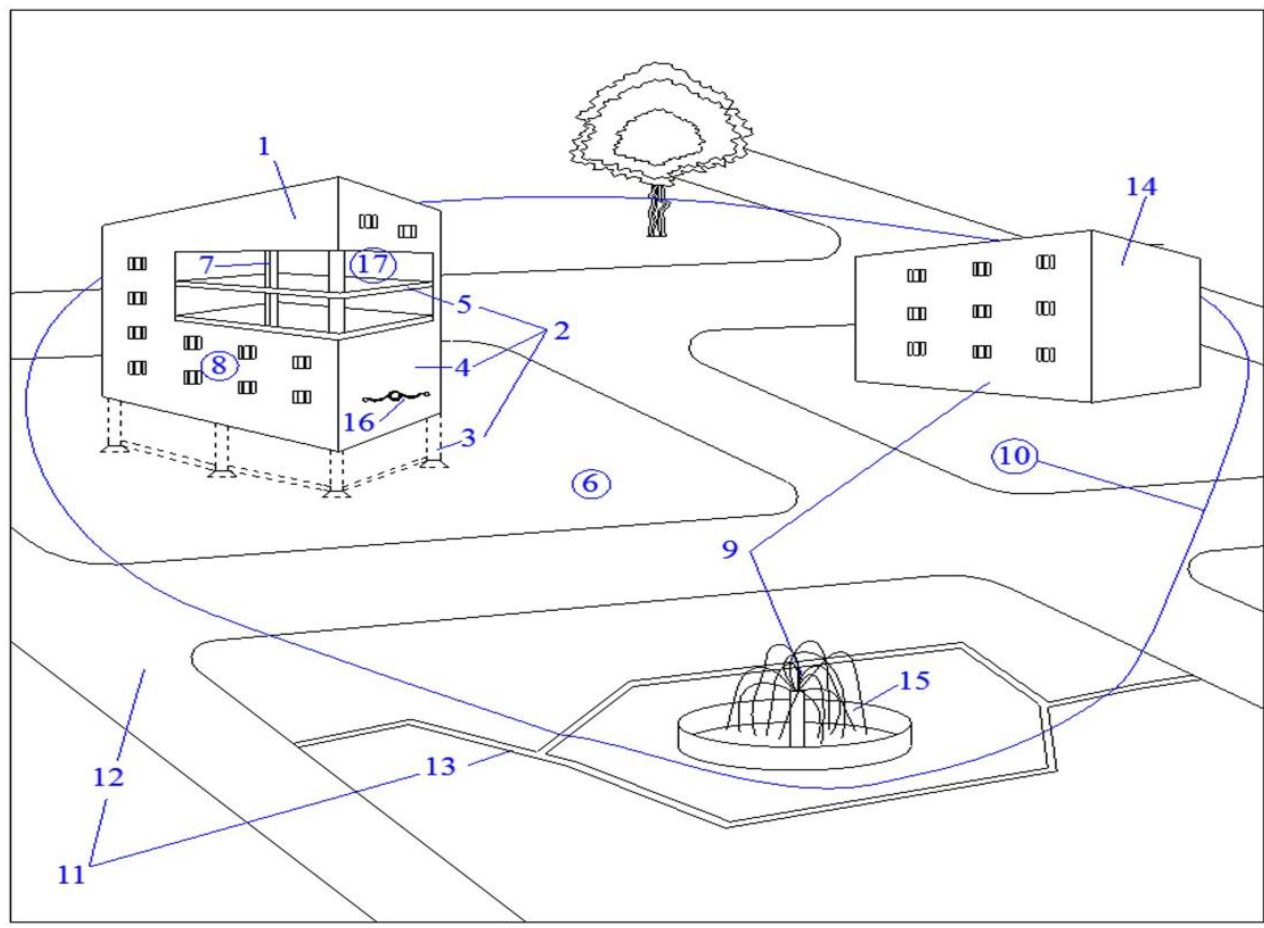

Fig.2. Diagram showing the historic monument in its urban setting.

\section{Discussion}

The authors' systematic approach is explained by the diagram in Figure 2. It illustrates a building of historical architectural heritage within its adjacent territory. The numeric annotations indicate the following: 1 - the building of historical architectural heritage, 2 structural elements of the building: 3 - foundations, 4 - structural walls, 5 - structural floors. Further: 6 - building site, 7 - new structural elements, 8 - façade, 9 - surrounding buildings, 10 - adjacent territory, 11 - transport and pedestrian infrastructure: 12 - roads, 13 - pavements; 14 - social infrastructure facilities, 15 - historical and cultural landmark, 16 - historical architectural-constructional decorative feature, 17 - interior space.

While investigating the town planning features of the immediate urban environment (stage 1) the extent and condition of the transport and pedestrian infrastructure (11) of the district, the extent of development of social infrastructural facilities (14), and the number and function of historical and cultural landmarks (15) in the area adjacent (10) to the building of historical and cultural heritage should be identified. When assessing the historical and architectural value of the property the historical period to which it belongs should be confirmed, its architectural style identified and the condition of the historic architectural-structural decorative features (16) should be assessed.

Assessment of the dilapidation of the property and its suitability for further exploitation should include examination of its load-bearing elements: foundations (3), structural walls (4), structural floors (5) etc. When analysing the relationship between the property under investigation and the architectural character of the surrounding properties (9) it is necessary to consider the following: the scale (dimensions) of the building in relation to neighbouring structures, the stylistic particularities of the building in the context of the architectural 
fabric of the district in question, the visual attractiveness of the site as a whole and also the dialogue with other nearby historical and cultural landmarks (15).

A programme of conservation should define both the methodologies of building preservation adopted and detailed constructional and organisational proposals. The selection of preservation methodologies depends on the condition of the building. If the building is in satisfactory condition, works may include the restoration of the façade (8), and if necessary, reinstatement of the original interior layout. Where structural problems are present, works may involve reinforcement of load-bearing structural elements (2) in addition to façade restoration (8). If the building is in a poor condition, works will include the replacement of failed structural elements (2), façade restoration '(8) and re-planning of the interior layout (17) to suit the proposed new building function.

In Stage 4, the historical and architectural evaluation of the restored property in relation to the aesthetic and architectural character of the adjacent territory, the building in question must be understood within the context (10) as a whole. This final stage should include identification of required improvements of the adjacent territory (10) including, for example, construction of fountain ensembles and minor architectural interventions, separation of parking and recreational zones, and so on.

The proposed systematic approach allows the scope of work for the conservation and renovation of historical architectural heritage to be justified. Additionally, the realisation of the described approach will make historical and cultural heritage properties and their adjacent areas more attractive, resulting in increased visitor numbers. The proposed method facilitates both the creation and the regeneration of spaces for recreation and consequently an increase in foot-fall within the adjacent social infrastructure, resulting from the broadened possibilities for cultural-aesthetic recreation, particularly for children and elderly citizens.

\section{Conclusions}

The main conclusions can be formulated as follows:

1. The construction of large industrial facilities and associated installations has played a formative role in the historical development of the character of Central Russian cities founded on the banks of major rivers. In the present day, much of the historically valuable architectural fabric is in decay. Considering this fact, a focal point of town planning policy should be the development and realisation of effective measures for the preservation and renovation of historical and architectural heritage.

2. The article details the authors' systematic approach for improving the methodology of restoration of historical architectural heritage. This approach includes implementation of research, preparatory, construction and completion stages. The characteristic feature of the authors' approach is the historical and architectural evaluation of the restored building in relation to the aesthetic and architectural qualities of the adjacent context.

3. The developed systematic approach allows the scope of work for the conservation and renovation of historical architectural heritage to be justified, making the property and its adjacent context more attractive and subject to increased visitor numbers.

\section{References}

1. .A. Sysoeva, Natural-science higher education: problems and outcomes, $42-44$ (2013)

2. T.V. Vavilonskaya, Vestnik MGSU 2, 14-17 (2009) 
3. V.A. Samogorov, O.S. Rybacheva, Vestnik of Volgograd State University of Architecture and Civil Engineering, Series: Construction and Architecture 31-1 (50), 300-304 (2013)

4. E.A. Sysoeva, Collection of abstracts of the 1st International Scientific and Practical Conference «Cultural heritage in XXIst century: «conservation, use and promotion», 65-68 (2012)

5. T.V. Vavilonskaya, News of Orel State Technical University, Series: Construction and Transport 3-23, 68-72 (2009)

6. T.V. Vavilonskaya, V.V. Alekseev, Traditions and Innovations in Construction and Architecture, 537-538 (2014)

7. T.V. Vavilonskaya, Architecture and Construction in Russia 12, 2-9 (2014)

8. E.A. Grintsevich, Economics and Enterprise 5 (22), 122-124 (2011)

9. E.M. Balzannikova, Traditions and Innovations in Construction and Architecture, 401404 (2012)

10. T.V. Baranova, N.A. Kosenkova, Synthetic image of orthodox architecture in the Middle Volga, Sacred architecture in shaping the identity of place, 149-157 (Politechnika Lubelska, Lublin, 2006)

11. M.I. Balzannikov, D.S. Privorotskiy, Architektura sakralna w ksztaltovaniu tozsamosci kulturowej miejsca, 345-357 (Wydawnictwo Politechniki Lubelskiej, Lublin, 2006).

12. E.M. Balzannikova, Vestnik MGSU 1, 15-24 (2014) 